SINERGI 2019, Volume 16 (2): 181-189

DOI : http://dx.doi.org/10.31963/sinergi.v16i2.1513

\title{
Evaluasi Sistem Pemanfaatan Energi Listrik di Grand Clarion Hotel Makassar
}

\author{
Herman Nauwir $^{1^{*}}$, kusmanurwira ${ }^{2}$, Alif Firdaus ${ }^{3}$ \\ 1,2,3 Jurusan Teknik Mesin, Politeknik Negeri Ujung Pandang, Makassar 90245, Indonesia \\ "hermannauwir@poliupg.ac.id
}

\begin{abstract}
In the hotel business, the use of energy is very important, especially in the use of electricity, the portion of usage and allocation of funds for its provision is the largest. It can be seen that equipment such as lights, elevators, refrigerators, laundry, heaters, pumps, to the air conditioning system are some of the dominant tools in operations in the hospitality world. The results of the initial energy audit and detailed audit at the Grand Clarion Hotel Makassar showed that the Energy Consumption Intensity (IKE) is still far from the standard, which is 300 $\mathrm{kWh} / \mathrm{m} 2$ a year. The building uses the largest amount of electricity in the Grand Clarion Hotel Makassar in Building $A$, which is in the Guest Room area of the air conditioning unit. The results of the initial energy audit of Energy Consumption Intensity (IKE) electricity were $336.84 \mathrm{kWh} / \mathrm{m} 2$ year. Whereas based on the results of a detailed energy audit the electricity consumption intensity (IKE) of electricity is $395.51 \mathrm{kWh} / \mathrm{m} 2$ a year. Energy Saving Opportunities (PHE) in this energy audit is to evaluate the AC power in each room and recommend the replacement of lamp types. From the results of the IKE calculation after the application of PHE, it is found that the value is still quite high so that efforts to save must still be done.
\end{abstract}

Keywords: Energy Audit, Energy Saving, t-test

Abstrak: Dalam bisnis perhotelan, penggunaan energi sangatlah penting, terutama dalam penggunaan energi listrik, porsi pemakaian serta alokasi dana untuk penyediaannya adalah yang terbesar. Hal ini dapat dilihat bahwa peralatan seperti lampu-lampu, lift, lemari es, laundry, pemanas, pompa-pompa, sampai pada sistem pengkondisian udara adalah beberapa alat yang dominan dalam operasional di dunia perhotelan. Hasil audit energi awal dan audit rinci di Grand Clarion Hotel Makassar menunjukkan Intensitas Konsumsi Energi (IKE) masih jauh dari standar, yaitu sebesar $300 \mathrm{kWh} / \mathrm{m}^{2}$ tahun. Bangunan penggunaan energi listrik terbesar di Grand Clarion Hotel Makassar pada Gedung A, yaitu di area Guest Room pada unit pengkondisian udara. Hasil audit energi awal Intensitas Konsumsi Energi (IKE) listrik adalah sebesar 336,84 kWh/m ${ }^{2}$ tahun. Sedangkan berdasarkan hasil audit energi rinci Intensitas Konsumsi Energi (IKE) listrik adalah sebesar 395,51 $\mathrm{kWh} / \mathrm{m}^{2}$ tahun. Peluang Hemat Energi (PHE) pada audit energi ini adalah mengevaluasi daya AC pada tiap kamar serta merekomendasikan penggantian jenis lampu. Dari hasil perhitungan IKE setelah penerapan PHE, didapati nilai yang masih cukup tinggi sehingga usaha penghematan masih harus dilakukan.

Kata kunci : Audit Energi, Hemat Energi, Uji-t

\section{PENDAhuluaN}

Energi listrik merupakan energi yang sangat vital dalam operasional perusahaan. Hampir semua peralatan dan sumber penerangan yang digunakan berasal dari energi listrik. Namun dalam pemakaiannya banyak dikeluhkan adanya ketidak-efisiensian energi listrik ini. Hal ini terbukti dari membengkaknya tagihan listrik yang dibayarkan per bulannya. Terlebih apabila ini terjadi di lingkungan kantor, perusahaan, maupun perhotelan, maka akan mengakibatkan anggaran biaya yang cukup besar.

Tingkat efisiensi pemakaian energi listrik dipengaruhi oleh daya listrik yang terpasang, aktivitas yang dilakukan, jenis peralatan yang terpasang, dan rata- rata pemakaian energi listrik per hari atau per bulan. Untuk mengefisiensikan pemakaian energi listrik, maka perlu dilakukan manajemen audit energi listrik dimana dengan audit tersebut akan didapatkan potret penggunaan energi listrik pada suatu bangunan, mengetahui kondisi peralatan yang terpasang, dan mengetahui peluang untuk penghematan energi. 
Tujuan dari penelitian adalah untuk menentukan Intensitas Konsumsi Energi (IKE) serta biaya pembayarannya sesuai pemakaian berdasarkan data historisis hotel dan mengidentifikasi peluangpeluang untuk penghematan energi di Grand Clarion Hotel Makassar.

\section{A. Hemat Energi}

Kegiatan hemat energi adalah tindakan mengurangi jumlah penggunaan energi. Hemat energi dapat dicapai dengan penggunaan energi secara efisien dimana manfaat yang sama diperoleh dengan menggunakan energi lebih sedikit, ataupun dengan mengurangi konsumsi dan kegiatan yang menggunakan energi.

\section{B. Audit Energi}

Audit energi adalah proses evaluasi pemanfaatan energi dan identifikasi peluang penghematan energi serta rekomendasi peningkatan efisiensi pada pengguna sumber energi dan pengguna energi dalam rangka konservasi energi [1].

\section{Intensitas Konsumsi Energi ( IKE )}

Intensitas Konsumsi Energi (IKE) listrik merupakan istilah yang digunakan untuk mengetahui besarnya pemakaian energi pada suatu system (bangunan). Namun, energi yang dimaksudkan dalam hal ini adalah energi listrik. Pada hakikatnya, Intensitas Konsumsi Energi ini adalah hasil bagi antara konsumsi energi total selama periode tertentu (satu tahun) dengan luasan bangunan. Satuan IKE adalah $\mathrm{kWh} / \mathrm{m}^{2}$ per tahun. Pemakaian IKE ini telah ditetapkan di berbagai Negara, antara lain ASEAN dan APEC. Menurut hasil penelitian yang dilakukan oleh ASEAN-USAID pada tahun 1987 yang laporannya baru dikeluarkan tahun 1992, target besarnya IKE listrik untuk Indonesia adalah sebagai berikut [2] :

IKE untuk perkantoran ( komersial ) $: 240 \mathrm{kWh} / \mathrm{m}^{2}$ per tahun

IKE untuk pusat belanja : $330 \mathrm{kWh} / \mathrm{m}^{2}$ per tahun

IKE untuk hotel atau apartemen : $300 \mathrm{kWh} / \mathrm{m}^{2}$ per tahun

IKE untuk rumah sakit : $380 \mathrm{kWh} / \mathrm{m}^{2}$ per tahun

Kategori di atas berdasarkan jumlah energi yang digunakan per tahun $(\mathrm{kWh})$, luas lantai total $\left(\mathrm{m}^{2}\right)$, dan jam operasi per tahun (2000 jam). Dalam menghitung IKE listrik pada bangunan gedung, ada beberapa istilah yang digunakan, antara lain [3]:

IKE listrik per satuan luas kotor (gross) gedung

Luas kotor (gross) $=$ Luas total gedung yang dikondisikan (ber-AC) ditambah dengan luas gedung yang tidak dikondisikan

IKE listrik per satuan luas total gedung yang dikondisikan (net)

IKE listrik per satuan luas ruang dari gedung yang disewakan (net product)

Adapun perhitungan IKE adalah $\mathrm{kWh}$ total / Luas Bangunan 


\section{Dasar Perhitungan Beban Kalor}

1) Kalor sensibel daerah perimeter ( tepi )

a) Tambahkan kalor oleh transmisi radiasi matahari melalui jendela $=($ Luas jendela $) x($ Jumlah radiasi matahari $) x($ Faktor transmisi jendela $)$ $x$ (Faktor bayangan )

b) Beban transmisi kalor melalui jendela $=($ Luas jendela $) x$ ( Koefisien transmisi kalor melalui jendela $) x($ Selisih temperatur interior dan eksterior )

c) Infiltrasi beban kalor sensible

$=\{($ volume ruangan $x$ jumlah penggantian ventilasi alamiah $)-$ jumlah udara luar $\} \times 0,24$ / volume apeeipic ( Selisih temperatur eksterior dan interior )

d) Beban transmisi kalor melalui dinding dan atap

$=($ Luas dinding $) x$ ( Koefisien mission transmisi kalor dari dinding $) x($ Selisih temperatur ekivalen dari radiasi matahari + selisih temperatur ekivalen dari temperatur atmosfir )

$=($ Luas atap ) $x$ ( Koefisien transmisi kalor $K$ dari atap ) $x$ ( Selisih temperatur ekivalen dari radiasi matahari + selisih temperatur ekivalen dari temperatur atmosfir )

e) Beban kalor tersimpan dari ruangan dengan penyegaran udara

$=($ pendinginan $)$ terputus - putus. Untuk keadaan dimana penyegaran udara dimulai 2 atau 3 jam sebelum waktu terjadinya beban kalor maksimum $(3+4+5+6+7+8) \times($ faktor beban kalor tersimpan $)$

\section{2) Beban kalor laten daerah perimeter}

a) Beban kalor laten oleh infiltrasi

$=($ Volume ruangan $) x$ (Jumlah ventilasi alamiah $) x 597,3 \times($ Selisih perbandingan kelembaban di dalam dan di luar ruangan )

\section{3) Beban kalor sensibel daerah interior}

a) Koefisien transmisi kalor dari partisi langit-langit dan lantai $=($ Luas langit - langit ) $x$ ( Koefisien transmisi kalor $K$ dari langit- langit ) $x$ ( Selisih temperatur dalam dan luar ruangan ) ( 9 )

$=($ Luas lantai $) x$ ( Koefisien transmisi kalor $K$ dari lantai ) $x$ ( Selisih temperatur dalam dan luar ruangan )

b) Beban kalor sensibel karena adanya sumber kalor interior

$=($ Jumlah orang $) x$ ( Kalor sensibel manusia ) ( Koreksi faktor kelompok )

$=($ Peralatan $\mathrm{kW}) x 0,860 \mathrm{kcal} / \mathrm{kW} x$ Faktor penggunaan peralatan

(12)

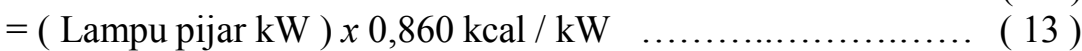

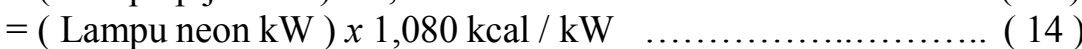

$=$ Sumber kalor sensibel lainnya

\section{4) Beban kalor laten daerah interior}

a) Tambahkan kalor laten oleh sumber penguapan interior

$=($ Jumlah orang $) x$ ( Kalor laten manusia $) x$ ( Koreksi faktor kelompok ) 


\section{5) Beban kalor sensibel mesin}

a) Tambahan kalor ( heat gain) sensibel oleh udara luar masuk $=($ Jumlah udara luar $) \div($ Volume spesifik udara luar $) \times 24 \mathrm{kcal} / \mathrm{kg}$

$x$ (Selisih temperatur dalam dan luar)

b) Beban kalor sensibel ruangan total

$=($ Total $1+$ Total 3$)$

c) Kenaikan beban oleh kebocoran saluran udara

$=(\mathrm{a}+\mathrm{b}+\mathrm{c}) x($ Faktor kebocoran saluran udara $)$

\section{6) Beban kalor laten mesin}

a) Beban kalor laten oleh udara luar masuk

$=($ Jumlah udara luar masuk quantity $) \div($ Volume spesifik udara luar

) $x$ ( Selisih faktor pencampuran uap di dalam dan luar ruangan )

Beban kalor laten ruangan total

$=($ Total 2 dan Total 4$)$

c) Kenaikan beban oleh kebocoran saluran udara

$=(\mathrm{a}+\mathrm{b}) x($ Faktor kebocoran saluran udara $)$

\section{METODE PENELITIAN}

Metode yang digunakan pada penelitian ini, yaitu metode deskriptif kasuistik disertai bantuan uji statistik. Dalam proses ini juga meliputi adanya audit energi. Audit energi ini meliputi dua tahap, yakni audit energi awal dan audit energi rinci.

\section{A. Audit Energi Awal}

Audit energi awal listrik dilakukan dengan mengacu pada standar audit energi listrik SNI 03 6196 - 2000 [4]. Profil pemakaian energi listrik dalam kegiatan perhotelan dikenali berdasarkan historisis pemakaian energi listrik.

\section{B. Audit Energi Rinci}

1. Pengumpulan dan penyusunan data energi bangunan hotel

2. Menghitung besarnya Intensitas Konsumsi Energi ( IKE ) bangunan

Audit energi rinci dilakukan apabila nilai Intensitas Konsumsi Energi ( IKE ) bangunan lebih besar dari target nilai IKE standar.

1. Penelitian dan pengukuran konsumsi energi 
2. Pengukuran energi

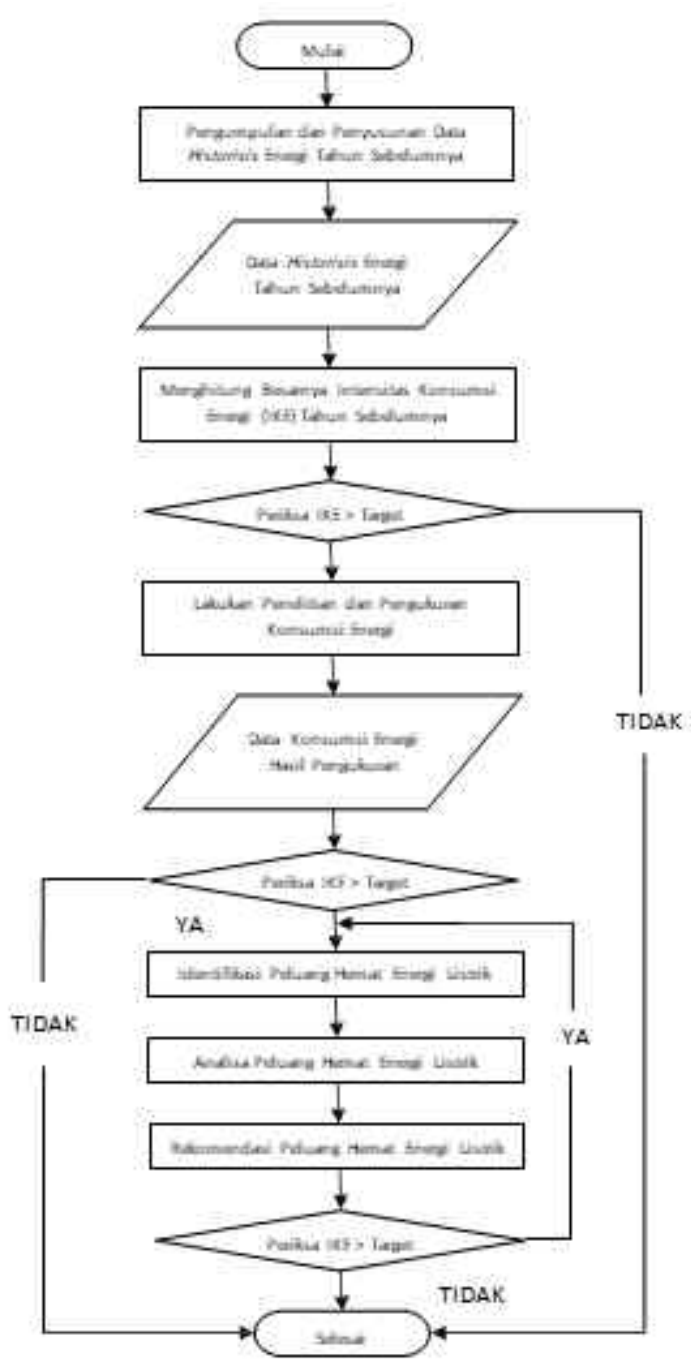

Gambar 1. Diagram Alir Penelitian

\section{HASIL DAN PEMBAHASAN}

\section{Audit Energi Awal}

Nilai Intensitas Konsumsi Energi (IKE) listrik di Grand Clarion Hotel Makassar dapat diketahui dengan menggunakan data historisis pada tahun 2013. Dari perhitungan di atas dapat diperoleh besarnya IKE listrik mula- mula per satuan luas yang dikondisikan ( net area) adalah $336,84 \mathrm{kWh} / \mathrm{m}^{2}$ tahun. Sedangkan target IKE per satuan luas yang dikondisikan untuk perhotelan adalah $300 \mathrm{kWh} / \mathrm{m}^{2}$ tahun.

Namun sebelum dilakukan audit energi rinci, maka IKE listrik diperiksa dengan mengacu pada standar yang ditetapkan oleh ASEAN - USAID tahun 1987. Pemeriksaan kesesuaian menggunakan bantuan pengujian statistik uji distribusi $-\mathrm{t}(\mathrm{uji}-\mathrm{t})$ dengan standar IKE sebesar $300 \mathrm{kWh} / \mathrm{m}^{2}$ tahun bagi perhotelan. Perhitungan nilai skor dan nilai - $t$ uji serta pembandingan keputusan untuk uji satu arah kanan dengan tingkat signifikansi 0,05 dan sampel $\mathrm{n}=12$ didapatkan bahwa nilai $\mathrm{t}$ hitung $=4,61$ lebih besar daripada nilai $\mathrm{t}$ tabel $=1,796$. Dengan demikian hipotesis awal yang dikemukakan ditolak sehingga harus diterima. Jadi hipotesis berlaku bahwa nilai IKE listrik melebihi dari standar yang ditetapkan. 


\section{Audit Energi Rinci}

Hasil pengukuran kWh meter di Grand Clarion Hotel Makassar didapatkan nilai rata-rata per hari sebesar $43380 \mathrm{kWh} / \mathrm{hari}$ dan nilai ini berada pada bulan Mei dengan occupancy rate sebesar 77,8 \% sehingga untuk satu bulan ini diperoleh nilai $\mathrm{kWh}$ sebesar $1.344 .780 \mathrm{kWh} / \mathrm{bulan}$. Untuk nilai $\mathrm{kWh}$ per bulan yang lain dapat dilihat pada tabel di bawah :

Tabel 1. Konsumsi energi listrik per bulan Tahun 2013

\begin{tabular}{|c|c|c|}
\hline Bulan & Occupancy Rate (\%) & $\mathbf{k W h}$ \\
\hline Januari & 67,5 & $1.166 .743,57$ \\
\hline Februari & 70,8 & $1.223 .784,37$ \\
\hline Maret & 77,9 & $1.346 .508,51$ \\
\hline April & 75,5 & $1.305 .024,29$ \\
\hline Mei & 77,8 & $1.344 .780,00$ \\
\hline Juni & 79,4 & $1.372 .436,14$ \\
\hline Juli & 68,6 & $1.185 .757,17$ \\
\hline Agustus & 55,1 & $952.408,46$ \\
\hline September & 82,5 & $1.426 .019,92$ \\
\hline Oktober & 90,8 & $1.569 .486,17$ \\
\hline November & 84,8 & $1.465 .775,63$ \\
\hline Desember & 68,0 & $1.175 .386,12$ \\
\hline & & $\mathbf{1 5 . 5 3 4 . 1 1 0 , 3 6}$ \\
\hline
\end{tabular}

Sehingga nilai Intensitas Konsumsi Energi (IKE) dapat dihitung, yaitu sebesar 395,51 kWh/m² tahun. Dari hasil perhitungan di atas dapat diperoleh besarnya IKE listrik hasil pengukuran (audit energi rinci) adalah sebesar $395,51 \mathrm{kWh} / \mathrm{m}^{2}$ tahun. Dari hasil audit awal diperoleh nilai IKE listrik per satuan luas yang dikondisikan adalah sebesar $336,84 \mathrm{kWh} / \mathrm{m}^{2}$ tahun.

\section{Identifikasi Peluang Hemat Energi}

Profil pemakaian energi listrik di Grand Clarion Hotel Makassar terbagi menjadi dua bagian, yakni Gedung A dan Gedung B. Untuk Gedung B, data - data pemakaian energi listrik masih belum valid sehingga profil pemakaian energi listrik dilakukan di Gedung A

Tabel 2 Presentase daya terpasang pada beban di Gedung A

\begin{tabular}{|r|l|c|c|}
\hline No. & \multicolumn{1}{|c|}{ Area } & Daya (kW) & Persentase (\%) \\
\hline 1 & Convention (Sandeq A / B / C ) & 109,96 & 4,31 \\
\hline 2 & Entertainment ( Studio 33, Redtro, d'Liquid ) & 697,94 & 27,35 \\
\hline 3 & Laundry & 74,96 & 2,94 \\
\hline 4 & Locker, Linen, HK, Canteen, HRD, dan QTS & 29,39 & 1,15 \\
\hline 5 & Meeting Rooms & 157,84 & 6,18 \\
\hline 6 & ME Equipment & 305,03 & 11,95 \\
\hline 7 & 333 Guest Rooms & 1169,36 & 45,82 \\
\hline 8 & Top Level Trat Daya & 7,84 & 0,31 \\
\hline \multicolumn{2}{|r|}{ Total } & $\mathbf{2 5 5 2 , 3 2}$ & $\mathbf{1 0 0}$ \\
\hline
\end{tabular}

Dari Tabel 2 di atas menunjukkan bahwa nilai daya terpasang yang terbesar terdapat pada area Guest Room dengan nilai kapasitas daya sebesar 1169,36 kW atau $46 \%$ dari total daya 
yang terpasang di Gedung A.

Tabel 3 Profil konsumsi energi listrik di Gedung A

\begin{tabular}{|c|l|c|c|}
\hline No. & \multicolumn{1}{|c|}{ Konsumsi Energi } & Daya (kW) & Persentase (\%) \\
\hline 1 & Unit Pengkondisian Udara & 1093,46 & 42,84 \\
\hline 2 & Unit Penerangan & 292,15 & 11,45 \\
\hline 3 & Unit Tenaga & 391,21 & 15,33 \\
\hline 4 & Unit Sistem Pendingin & 41,11 & 1,61 \\
\hline 5 & Utility & 734,39 & 28,77 \\
\hline \multicolumn{2}{|c|}{ Total } & $\mathbf{2 5 5 2 , 3 2}$ & $\mathbf{1 0 0}$ \\
\hline
\end{tabular}

Dari Tabel 3 di atas menunjukkan bahwa nilai konsumsi terbesar energi listrik di Gedung A adalah unit pengkondisian udara dengan nilai konsumsi daya sebesar 1093,46 $\mathrm{kW}$ atau $43 \%$ dari total konsumsi listrik.

\section{Analisis Peluang Hemat Energi}

Untuk memperoleh kenyamanan dalam kamar hotel, maka diperlukan sistem pengkondisian udara, yaitu berupa AC (Air Conditioning). AC ini akan mengatur suhu pada suatu ruangan sesuai dengan temperatur yang digunakan oleh pengguna. Untuk temperatur masing-masing kamar hotel diatur oleh pihak manajemen dengan temperatur $22^{\circ} \mathrm{C}-24^{\circ} \mathrm{C}$. Besarnya tingkat konsumsi energi listrik untuk sistem pengkondisian udara dipengaruhi oleh total daya $\mathrm{AC}$, jumlah, dan lama waktu beroperasi dari AC untuk tiap ruangan kamar hotel [5].

Adapun total jumlah daya nilai unit pengkondisian udara adalah sebesar 595 PK atau setara dengan 434,35 $\mathrm{kW}$ dan total konsumsi energi dapat dihitung denagn mengasumsikan unit pengkondisian udara menyala selama 24 jam dengan $\cos \varphi$ sebesar 0,99 maka total konsumsi energi listrik sebesar 10320,16 kWh.

Sedangkan untuk unit penerangan pola konsumsi energi listrik untuk sistem pencahayaan dipengaruhi oleh beberapa faktor, yaitu jenis atau tipe lampu, jumlah lampu serta waktu nyala atau beroperasi dari lampu tersebut.

Adapun jumlah total daya nilai untuk unit penerangan adalah sebesar $38,80 \mathrm{~kW}$ dan total konsumsi energi dapat dihitung dengan mengasumsikan lampu menyala selama 24 jam dengan $\cos \varphi$ sebesar 0,99 maka total konsumsi energi listrik sebesar 921,91 kWh.

\section{Rekomendasi Peluang Hemat Energi}

Untuk rekomendasi peluang hemat energi di Gedung A Grand Clarion Hotel Makassar pada pemakaian pendingin ruangan ( $\mathrm{AC}$ ), diketahui bahwa jumlah total daya $\mathrm{AC}$ yang terpasang sebesar 434,35 kW yang tersebar di kamar-kamar hotel yang berkapasitas beragam antara 1,5 PK sampai 4 PK, baik itu dari lantai 5 sampai dengan lantai 17. Dalam peluang hemat ini akan dihitung seberapa besar kapasitas AC yang akan digunakan berdasarkan besar ruangan di kamarkamar hotel. Untuk mengevaluasi unit sistem pengkondisian udara di tiap-tiap tipe kamar, terlebih dahulu dihitung beban kalor di masing-masing tipe kamar.

Nilai total kebutuhan AC di Gedung A setelah evaluasi adalah sebesar 297,48 kW dengan total konsumsi energi listrik sebesar 7068,01 kWh. Terlihat bahwa setelah mengevaluasi unit sistem pengkondisian udara berdasarkan beban kalor dan kebutuhan AC di tiap kamar hotel pada Gedung A menunjukkan bahwa adanya penurunan total konsumsi energi listrik dari nilai total aktual konsumsi energi listrik sebesar 10320,16 kWh menjadi sebesar 7068,01 kWh.

Selain dilakukan evaluasi penghematan energi listrik di tiap kamar hotel pada unit pengkondisian udara dilakukan juga evaluasi penghematan listrik di tiap kamar pada unit penerangan atau pencahayaan dan salah satu evaluasi penghematan energi listrik pada unit 
penerangan di dalam kamar di Grand Clarion Hotel Makassar pada Gedung A, yaitu dengan rekomendasi penggantian jenis lampu dengan daya yang lebih kecil namun memiliki nilai lumen yang sama.

Nilai daya total penggunaan lampu setelah rekomendasi penggantian lampu room Gedung A adalah sebesar $14,99 \mathrm{~kW}$ dengan total konsumsi energi listrik sebesar 356,23 kWh. Terlihat bahwa setelah rekomendasi penggantian jenis lampu di tiap kamar hotel pada Gedung A menunjukkan bahwa adanya penurunan total konsumsi energi listrik dari nilai total aktual konsumsi energi listrik sebesar 921,91 kWh menjadi sebesar 356,23 kWh.

\section{Menghitung Intensitas Konsumsi Energi}

Dari hasil evaluasi dan rekomendasi di atas dapat diperoleh jumlah pemakaian energi untuk unit sistem pengkondisian udara dan unit penerangan di kamar-kamar hotel Gedung A Grand Clarion Hotel Makassar setelah dilakukan peluang hemat energi (PHE). Untuk lebih jelasnya dapat dilihat pada tabel di bawah ini.

Tabel 4 Konsumsi Energi Sesudah PHE di Kamar Hotel Gedung A

\begin{tabular}{|c|c|c|c|c|}
\hline \multirow[b]{2}{*}{ No. } & \multirow[b]{2}{*}{ Konsumsi Energi } & \multicolumn{3}{|c|}{ Konsumsi Energi } \\
\hline & & $\begin{array}{c}\text { Sebelum PHE } \\
\text { kWh }\end{array}$ & $\begin{array}{c}\text { Sesudah PHE } \\
\text { kWh }\end{array}$ & $\begin{array}{c}\text { Selisih } \\
\text { kWh }\end{array}$ \\
\hline 1 & Unit Pengkondisian Udara & 10320,16 & 7068,10 & 3252,06 \\
\hline 2 & Unit Penerangan & 921,91 & 356,23 & 565,68 \\
\hline & TOTAL & 11242,07 & 7424,33 & 3817,74 \\
\hline
\end{tabular}

Dari tabel di atas diperoleh hasil selisih sebelum dan sesudah PHE yang menunjukkan energi listrik per hari sebesar $3817,74 \mathrm{kWh}$, maka dapat dihitung jumlah energi listrik untuk unit pengkondisian udara dan unit penerangan yang terpakai selama satu bulan adalah sebesar 114.532,2 kWh / bulan. Dan jumlah untuk pemakaian energi listrik selama satu tahun adalah : 12 Bulan $x$ Jumlah $\mathrm{kWh}$ selama 1 Bulan $=12 \times 114.532,2 \mathrm{kWh}=1.374 .386,4$ $\mathrm{kWh} /$ tahun

Sehingga dari data konsumsi energi listrik dan data luasan bangunan serta nilai occupancy rate di Grand Clarion Hotel Makassar berdasarkan analisis Peluang Hemat Energi (PHE) yang telah diperoleh, maka dapat dihitung besarnya IKE Grand Clarion Hotel Makassar selama satu tahun. Adapun perhitungannya adalah sebagai berikut $360,52 \mathrm{kWh} / \mathrm{m}^{2}$ tahun

Dari perhitungan di atas dapat diperoleh besarnya IKE listrik adalah sebesar 360,52 $\mathrm{kWh} / \mathrm{m}^{2}$ tahun. Ternyata nilai IKE rekomendasi Peluang Hemat Energi (PHE) pada Grand Clarion Hotel Makassar tidak sesuai dengan IKE listrik yang ditentukan untuk perhotelan sebesar $300 \mathrm{kWh} / \mathrm{m}^{2}$ tahun. Ini dikarenakan perhitungan pada identifikasi, analisis, dan rekomendasi hanya dilakukan pada Gedung A dan tidak dilakukan pada Gedung B.

\section{Uji Statistik dan Hipotesis}

Setelah dilakukan evaluasi penghematan energi, nilai IKE yang didapat masih melebihi dari standar IKE sebesar $300 \mathrm{kWh} / \mathrm{m}^{2}$ tahun. Jika setelah dilakukan penghematan energi di Gedung B, maka nilai IKE yang didapat sebesar $360,52 \mathrm{kWh} / \mathrm{m}^{2}$ tahun akan turun. Dengan demikian dilakukan pengujian satu arah sisi kanan.

$$
\begin{aligned}
& \text { Ho: } \mu \leq 360,52 \mathrm{kWh} / \mathrm{m}^{2} \text { tahun } \\
& \text { Ha }: \mu>360,52 \mathrm{kWh} / \mathrm{m}^{2} \text { tahun }
\end{aligned}
$$




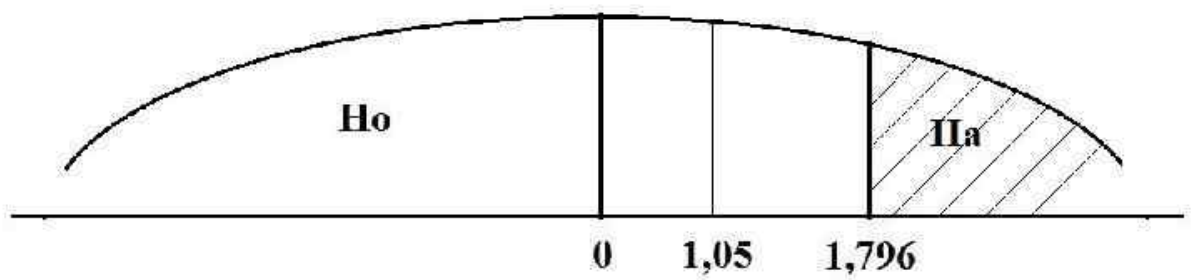

Gambar 2. Kurva hasil pengujian distribusi t satu arah sisi kanan

Nilai $\mathrm{t}$ hitung $=1,05$ lebih kecil daripada nilai $\mathrm{t}$ tabel $=1,796$. Dengan demikian kita terima Ho yang menyatakan bahwa setelah dilakukan penghematan energi di Gedung B, maka nilai IKE yang didapat sebesar $360,52 \mathrm{kWh} / \mathrm{m}^{2}$ tahun akan turun dan dapat turun hingga melewati standar IKE yang ditetapkan, yaitu sebesar $300 \mathrm{kWh} / \mathrm{m}^{2}$ tahun.

\section{KESIMPULAN}

Dari hasil analisis yang telah dilakukan, maka ada beberapa kesimpulan yang dapat diambil antara lain :

1. Berdasarkan audit energi awal, nilai Intensitas Konsumsi Energi (IKE) yang terbesar adalah untuk konsumsi energi listrik yaitu sebesar $336,84 \mathrm{kWh} / \mathrm{m}^{2}$ tahun dan berdasarkan hasil audit energi rinci adalah sebesar 395,51 kWh / $\mathrm{m}^{2}$ tahun. Dengan total konsumsi energi sebesar 13.229.853 $\mathrm{kWh}$ per tahun dan

total biaya yang harus dikeluarkan oleh pihak hotel sebesar Rp. 15.241.530.865,-per tahun

2. Peluang Hemat Energi ( PHE ) pada penelitian audit energi ini adalah sebagai berikut :

a. Setelah mengevaluasi unit sistem pengkondisian udara menunjukkan bahwa adanya penurunan total konsumsi energi listrik dari nilai total aktual konsumsi energi listrik sebesar 10320,16 kWh menjadi sebesar 7068,01 kWh.

b. Setelah rekomendasi penggantian jenis lampu menunjukkan bahwa adanya penurunan total konsumsi energi listrik dari nilai total aktual konsumsi energi listrik sebesar 921,91 kWh menjadi sebesar 356,23 kWh.

\section{DAFTAR PUSTAKA}

[1] Peraturan Menteri Energi dan Sumber Daya Mineral Republik Indonesia Nomor: 14 Tahun 2012 Tentang Manajemen Energi .

[2] ASEAN-USAID Building Energy Conservation Project.

[3] Badan Standarisasi Nasional. 2000. Prosedur Audit Energi pada Bangunan Gedung (SNI 03-6196-2000). Departemen Pendidikan Nasional.

[4] Badan Standarisasi Nasional. 2001. Tata Cara Perencanaan Sistem Pencahayaan Buatan pada Bangunan Gedung (SNI 03-6575-2001). Departemen Pendidikan Nasional.

[5] Arismunandar, Wiranto dan Heizo Saito. 2005. Penyegaran Udara. Jakarta: PT. Pradnya Paramita.

[6] Subiyakto, Haryono dan Algifari. 2001. Soal Jawab Statistika Induktif(Inferensi). Edisi Pertama. Yogyakarta: BPFE-Yogyakarta. 